\title{
ВЛИЯНИЕ ЭЛЕМЕНТОВ ТЕХНОЛОГИИ ВОЗДЕЛЫВАНИЯ НА ПРОДУКТИВНОСТЬ ОЗИМОЙ ВИКИ С ОЗИМОЙ РОЖЬЮ
}

\author{
A.A. Arefin
}

\section{THE INFLUENCE OF ELEMENTS OF CULTIVATION TECHNOLOGY ON THE PRODUCTIVITY OF WINTER VETCH WITH WINTER RYE}

\begin{abstract}
Арефин Алексей Алексеевич - директор ООО «Михайловское», Кемеровская обл., Прокопьевский р-н, с. Михайловка, соискатель кафр. агрономии, селекции и семеноводства Кузбасской государственной сельскохозяйственной академии, г. Кемерово. E-mail: razit2007@mail.ru
\end{abstract}

Цель исследования - изучить влияние сроков посева на продуктивность озимых культур в чистых и смешанных посевах в условиях Западной Сибири. Исследование проводилось на опытном поле ООО «Михайловское» Прокопьевского района Кемеровской области (лесостепная зона Западной Сибири) в 2015-2017 г2. Объектом исследований являются озимая вика сорта Фортуна и озимая рожь сорта Tетра короткая. Полевые опыты проводились в соответствии с методикой постановки полевого опыта. Варианты размещались рендомизированно в четырехкратной повторности. Площадь делянок в опытах - 200 м². Расположение делянок - систематическое. Предшественником исследуемых культур является чистьй пар. Соотношение компонентов в смеси: озимая рожь - $60 \%$, озимая вика - $40 \%$. Технология воздельвания озимых культур и смеси озимой вики с озимой рожью - общепринятая для условий зоны. Схема опыта полевого опыта: 1) посев 5 августа; 2) посев 15 августа; 3) посев 25 августа; 4) посев 5 сентября. Планируемая урожайность зерна в вариантах на уровне $2,5 \mathrm{~m} / 2 а$ (фон) подсчитали балансовым методом. Сроки посева культур, проведенные в период с 5 августа по 5 сентября, ссформировали урожайность зерна: озимой ржи - om 1,90 до 2,28 m/2a, озимой вики - от 1,70 до 2,37 m/2а, смеси «озимая рожь + озимая вика» - om 1,86 до 2,40 m/2а. Наибольшее накопление белка в зерне озимых культур отмеча-
Arefin Alexey Alexeyevich - Director, JSC "Mikhaylovskoe", Kemerovo Region, Prokopyevsk District, V. Mikhaylovka, Applicant, Chair of Agronomy, Selection and Seed Farming, Kuzbass State Agricultural Academy, Kemerovo.

E-mail: razit2007@mail.ru

лось в одновидовых агроценозах при посеве 5 августа: озимой ржи - 14,00 \%, озимой вики 24,00 \%. В смеси «озимая рожь + озимая вика» наибольщее накопление валового белка было получено при посеве 15 августа - 17,50\%. Биологическая эфффективность смеси «озимая рожь + озимая вика» по показателю LER во все сроки посева выше 1,0 и составил 1,04-1,12. Смесь «озимая рожь + озимая вика» в условиях лесостепи Западной Сибири во все сроки посева обеспечивает хозяйственную и биологическую эфффективность.

Ключевые слова: озимая рожь, озимая вика, смешанные посевы, урожайность, белок, показатель LER.

The research objective was to study the influence of the terms of sowing on the efficiency of winter crops in pure and mixed crops in the conditions of Western Siberia. The research was conducted on experimental field of JSC "Mikhaylovskoye" of Prokopyevsk area of Kemerovo Region (forest-steppe zone of Western Siberia) in 2015-2017. The objects of the researches were winter vetch varieties Fortuna and a winter rye of the variety Tetra short. Field experiments were made according to the technique of statement of field experiment. The options were placed at random in quadruple frequency. The area of the allotments in experiments was 200 sq.m. The arrangement of allotments was systematic. The predecessor of studied cultures was bare fallow. The ratio of 
the components in mix: winter rye - $60 \%$, winter vetch $-40 \%$. The technology of cultivation of winter crops and winter vetch mix with a winter rye was standard for zone conditions. The scheme of making field experiment: 1) sowing on August, 5; 2) sowing on August, 15; 3) sowing on August, 25; 4) sowing on September, 5. Planned productivity of grain in the options at the level of 2.5 thectare (background) counted by a balance method. The terms of sowing of cultures which were carried out to the period from August, 5 to September, 5 created productivity of grain: winter rye - from 1.90 to 2.28 t/hectare, winter vetch from 1,70 to 2,37 thectare, the mix "winter rye + winter vetch " - from 1,86 to $\quad 2,40$ t/hectare. The greatest accumulation of protein in grain of winter crops was noted in one-specific agrotsenoza at crops on August 5: a winter rye $-14.00 \%$, winter vetch $-24.00 \%$. In the mix "winter rye + winter vetch" the greatest accumulation of gross protein was received at crops on August, $15-17.50 \%$. Biological efficiency of the mix "winter rye + winter vetch" on LER index in all terms of crops higher than 1.0 also made 1.041.12. The mix "winter rye + winter vetch" in the conditions of forest-steppe of Western Siberia in all terms of crops provided economic and biological efficiency.

Keywords: winter rye, winter vetch, mixed crops, yield, protein, LER index.

Введение. В современных условиях ведения интенсивного животноводства полевое кормопроизводство будет доминировать над естественными кормовыми угодьями. Полевое кормопроизводство будет регулировать структуру сельскохозяйственных культур в севообороте, снижать насыщенность его зерновыми культурами, обеспечит плодосмен, положительно повлияет на продуктивность растений. Это очень важно, когда в настоящее время на практике происходит одностороннее увеличение возделывания экономически привлекательных культур (зерновые, подсолнечник) на пахотных землях, что приводит к нарушению чередования культур, ухудшению фитосанитарного состояния посевов, развитию процессов деградации сельскохозяйственных земель [1, 2]. Научно обоснованное развитие полевого кормопроизводства присуще не только крупным агрохолдингам, а также средним по объемам производства жи- вотноводческой продукции сельхозпредприятиям. В таких хозяйствах большую перспективу имеют культурные пастбища [3].

В современных мегафермах животные содержатся в течение года в стойловом режиме, где используется только монокорм. В условиях Западной Сибири готовить сочные корма (сенаж, силос) в необходимом количестве за счет кукурузы невозможно. Из-за ограниченности периода заготовки кормов необходимо изыскать другие источники сырья, в частности путем возделывания многолетних и однолетних трав на пашне. Среди однолетних трав особое место занимают озимые культуры, что позволяет начинать заготовки кормов в ранние периоды сезона. Например, из зеленой массы озимой ржи в ООО «Колос» Промышленновского района Кемеровской области заготавливают до 20 \% необходимого количества сенажа для хозяйства $[4,5]$. Озимая рожь, как самый ранний источник сырья, также успешно используется в зеленом конвейере во многих хозяйствах Западной Сибири $[6,7]$. Среди озимых культур высококачественная зеленая масса получается при посеве смеси озимой вики с озимыми злаковыми компонентами, в частности с озимой рожью [8]. С 2012 г. в ООО «Михайловское» Прокопьевского района данная смесь успешно возделывается на зеленый корм и для закладки зерносенажа $[9,10]$. Известно, что озимые культуры на корм можно использовать без применения средств химической защиты, что актуально в современных условиях, в частности в производстве экологически чистой продукции животноводства на основе органического земледелия [11].

Однако доля озимых культур в полевом кормопроизводстве Западной Сибири остается незначительной. В настоящее время площади возделывания озимой вики и ее смесей в хозяйствах Западной Сибири значительно сократились, хотя культура остается высокоэффрективной [12]. Продуктивность озимой вики зависит от сроков посева [13]. Данный вопрос в условиях Западной Сибири изучен недостаточно и является одной из причин низкой продуктивности агроценозов и малораспространенности культуры в условиях производства.

Цель исследования: изучить влияние сроков посева на продуктивность озимых культур в 
чистых и смешанных посевах в условиях Западной Сибири.

Объекты, условия и методика исследования. Исследование проводилось на опытном поле ООО «Михайловское» Прокопьевского района Кемеровской области (лесостепная зона Западной Сибири) в 2015-2017 гг.

По результатам агрохимических обследований полей ООО «Михайловское» содержание элементов питания в пахотном слое почвы составляет: гумус - 5,8 \%; $\mathrm{P}_{2} \mathrm{O}_{5}-87$ мг/кг; $\mathrm{K}_{2} \mathrm{O}-$ 93,3 мг/кг. Содержание доступного азота посчитали по методике, предложенной В.Г. Минеевым (2004) [14]. Содержание валового минерализованного азота $(\mathrm{N})$ в почве опытного поля составил $77 \mathrm{mr} / к г$.

Объектом исследования являются озимая вика сорта Фортуна и озимая рожь сорта Тетра короткая. Погодные условия в годы исследования были близки к многолетним данным и типичными для зоны.

Схема опыта полевого опыта: 1) посев 5 августа; 2) посев 15 августа; 3) посев 25 августа; 4) посев 5 сентября. Планируемая урожайность зерна в вариантах на уровне 2,5 т/га (фон) подсчитали балансовым методом [15]. Запасы подвижных форм фоссрора и калия в почве $\left(S_{n}\right)$ рассчитывали по методике, предложенной Л.М. Державиным, Р.Н. Поповой, Н.И. Дегяровой и Н.А. Мухой (1985) [16]:

$$
S_{n}=0,1 \times C_{n} \cdot h \cdot d,
$$

где $\mathrm{C}_{n}$ - содержание подвижных форм $\mathrm{P}_{2} \mathrm{O}_{5}, \mathrm{~K}_{2} \mathrm{O}$ или минерального азота в пахотном слое, мг/кг; $d$ - плотность пахотного слоя, г/см3; $h$ - мощность пахотного слоя - $30 \mathrm{~cm}$.

Коэффициент усвояемости растениями элементов питания из почвы составляет: азота $50 \%$, фоссфора - 10 и калия - $25 \%$ [17]. Наличие доступного количества элемента калия в почве исключило внесение калийсодержащих удобрений.

Полевые опыты проводились в соответствии с методикой постановки полевого опыта $[18,19]$. Варианты размещались рендомизированно в четырехкратной повторности. Площадь делянок в опытах - 200 м². Расположение делянок систематическое. Качество зерна озимых куль- тур определяли в ФГБУ ЦАС «Кемеровская» (г. Кемерово).

Предшественником исследуемых культур является чистый пар. Соотношение компонентов в смеси: озимая рожь - $60 \%$; озимая вика $40 \%$. Технология возделывания озимых культур и смеси озимой вики с озимой рожью общепринятая для условий зоны [20].

Результаты исследования и их обсуждение. Одной из основных причин низкой эффективности производства продукции животноводства в Сибирском федеральном округе является неустойчивость и слабая развитость кормовой базы в сельскохозяйственных предприятиях. Перспективы развития отрасли зависят от темпов роста обеспеченности сельскохозяйственных животных высококачественными кормами с повышенной концентрацией в сухом веществе обменной энергии, протеина и других нормируемых элементов питания, создания прочной кормовой базы на основе возделывания высокопротеиновых кормовых культур на зеленый корм, сенаж и силос в полевом кормопроизводстве. Среди них ведущее место занимают озимые культуры и их смеси, в частности озимая вика в одновидовых и смешанных посевах с озимыми злаковыми.

Основной озимой культурой в Западной Сибири из семейства Злаковые является озимая рожь. По химическому составу зерно озимой ржи близко к зерну яровой пшеницы, хотя существуют различия в белковом и углеводном комплексе. Содержание белка в зерне ржи колеблется от 6,5 до $14,5 \%$. Озимая рожь широко используется в продовольственных целях и на корм животным.

Озимая вика (Vicia villosa Roth.) является единственным видом из семейства Бобовые в озимой форме [21]. Озимая вика не только является высокобелковой культурой, но и накопителем биологического азота [22], тем самым повышает плодородие почвы.

Bce это позволяет при надлежащей подготовке поля получить высокие урожаи последующих сельскохозяйственных культур в севообороте.

Сроки посева озимых культур по-разному влияли на продуктивность растений как в одновидовых, так и бинарных посевах. Наибольшая урожайность зерна озимой ржи фрормируется 
при посеве с 15 по 25 августа. Известно, что растения озимых культур с оптимальным развитием в осенний период вегетации отличаются высокой зимостойкостью и продуктивностью. Напротив, переросшие растения снижают зимостойкость [23].

При раннем посеве растения прорастают в высоту и в результате изреживаются в период перезимовки. За годы исследования урожайность зерна озимой ржи изменилась от 1,90 т/га при посеве 5 сентября до 2,37 т/га при посеве 15 августа. Начиная со срока посева 25 августа, отмечалось снижение урожайности зерна культуры.

Аналогичные данные были получены по озимой вике. Ранний посев (5 августа) обеспечил интенсивный рост растений в высоту, что стало причиной выпревания в зимний период и снизило урожайность за счет гибели растений. Наибольшая урожайность зерна озимой вики была получена в варианте «посев 15 августа» 2,37 т/га. Начиная со срока посева 25 августа снижается урожайность зерна озимой вики. При посеве 5 сентября получена наименьшая урожайность зерна культуры - 1,7 т/га. За годы исследования было установлено, что плотность растений в смеси зависит от сроков посева. При раннем посеве (5 августа) в смеси по плотности растений существенной разницы не было
(60:40). В данном варианте урожайность зерна озимой ржи составила 1,45 т/га, озимой вики 0,75 т/га. Наибольшая урожайность зерна смеси получена при посеве 15 августа - 2,40 т/га. В данном варианте доля ржи в смеси составила $63 \%$, хотя продуктивность растений снижается в сравнении с вариантом «посев 5 августа» на 0,01 т/га. Доля растений озимой вики снизилась на $3 \%$ и составила $37 \%$. Несмотря на это, урожайность зерна озимой вики повысилась на 0,21 т/га в сравнении со сроком посева 5 августа за счет увеличения количества бобов на одном растении и массы 1000 семян.

Сроки посева влияют на видовой состав смеси. Во всех сроках посева доля растений озимой ржи остается выше в сравнении с растением озимой вики, хотя плотность между видами в агроценозе непостоянная. Доля озимой ржи изменилась от 55 \% (при посеве 5 сентября) до 63 \% (при посеве 15 августа).

Сроки посева с 5 по 25 августа незначительно повлияли на урожайность зерна озимой ржи в смеси - 1,44-1,47 т/га. При сроке посева 5 сентября данный показатель существенно снизился и составил 1,02 т/га. Урожайность зерна озимой вики в смеси аналогично повышается при сроке посева 25 августа, а затем снижается до 0,84 т/га в варианте «сроки посева 5 сентября» (табл. 1).

\section{Влияние сроков посева на урожайность зерна озимых культур, т/га (среднее за 2015-2017 гг.)}

\begin{tabular}{|c|c|c|c|c|c|c|c|}
\hline \multirow{3}{*}{ Срок посева } & \multirow{3}{*}{$\begin{array}{c}\text { Озимая } \\
\text { рожь }\end{array}$} & \multirow{3}{*}{$\begin{array}{c}\text { Озимая } \\
\text { вика }\end{array}$} & \multicolumn{5}{|c|}{ Смесь озимой вики с озимой рожью } \\
\hline & & & \multirow{2}{*}{ Общая } & \multicolumn{2}{|c|}{ Озимая рожь } & \multicolumn{2}{|c|}{ Озимая вика } \\
\hline & & & & $\%$ & т/га & $\%$ & T/га \\
\hline 05.08 & 2,03 & 2,15 & 2,20 & 60,00 & 1,45 & 40,00 & 0,75 \\
\hline 15.08 & 2,28 & 2,37 & 2,40 & 63,00 & 1,44 & 37,00 & 0,96 \\
\hline 25.08 & 2,23 & 2,28 & 2,38 & 61,00 & 1,47 & 39,00 & 0,91 \\
\hline 05.09 & 1,90 & 1,7 & 1,86 & 55,00 & 1,02 & 45,00 & 0,84 \\
\hline $\mathrm{HCP}_{05}$ & 0,11 & 0,15 & 0,12 & & & & \\
\hline
\end{tabular}

Сроки посева озимых культур влияют не только на урожайность зерна, но и на его качество, в частности на содержание сырого белка в одновидовых и в бинарных посевах.

Содержание белка в зерне озимой ржи изменилось от 11,50 \% при сроке посева 5 сентября до 14,00 \% при сроке посева 5 августа. Наи- большее накопление белка $(14,00 \%)$ отмечалось при раннем сроке посеве - 5 августа.

Это объясняется тем, что озимые культуры с осени накапливают наибольшее количество питательных веществ в корневой системе, и, несмотря на относительную гибель растений в зимний период, выжившие растения развивают- 
ся более интенсивно, и повышается качество зерна, в частности содержание белка.

Содержание белка в зерне озимой вики снизилось от сроков посева - от 24,00 \% (в варианте «сроки посева 5 августа») до 20,00 \% (в варианте «сроки посева 5 сентября»). В одновидовых посевах озимая рожь и озимая вика накапливают наибольшее количество белка в пе- риод посева с 15 по 25 августа: у озимой ржи $24,00-23,50 \%$, у озимой вики - 24,00-23,50 \%.

Сбор белка с 1 га у озимой ржи повышается до 25 августа, затем начинается снижение данного показателя. Сбор белка с 1 га в зерне озимой вики составил от 0,34 т/га (20,00 \% в варианте «сроки посева 5 сентября») до 0,52 т/га (24,00 \% в варианте «сроки посева 5 августа») (табл. 2).

Таблица 2

\section{Влияние сроков посева на качество зерна озимых культур (среднее за 2015-2017 гг.)}

\begin{tabular}{|c|c|c|c|c|c|c|c|c|c|c|}
\hline \multirow{3}{*}{$\begin{array}{c}\text { Срок } \\
\text { посева }\end{array}$} & \multirow{2}{*}{\multicolumn{2}{|c|}{$\begin{array}{c}\text { Озимая } \\
\text { рожь }\end{array}$}} & \multirow{2}{*}{\multicolumn{2}{|c|}{$\begin{array}{c}\text { Озимая } \\
\text { вика }\end{array}$}} & \multicolumn{6}{|c|}{ Зерносмесь } \\
\hline & & & & & \multicolumn{2}{|c|}{ Озимая рожь } & \multicolumn{2}{|c|}{ Озимая вика } & \multicolumn{2}{|c|}{ Зерносмесь } \\
\hline & $\%$ & т/га & $\%$ & т/гa & $\%$ & т/га & $\%$ & т/га & $\%$ & т/га \\
\hline 05.08 & 14,00 & 0,28 & 24,00 & 0,52 & 14,00 & 0,20 & 24,10 & 0,18 & 17,30 & 0,38 \\
\hline 15.08 & 13,00 & 0,28 & 23,50 & 0,49 & 13,10 & 0,19 & 23,9 & 0,23 & 17,50 & 0,42 \\
\hline 25.08 & 12,60 & 0,27 & 21,00 & 0,48 & 13,00 & 0,19 & 23,00 & 0,21 & 16,81 & 0,40 \\
\hline 05.09 & 11,50 & 0,22 & 20,00 & 0,34 & 12,5 & 0,13 & 20,10 & 0,17 & 16,13 & 0,30 \\
\hline
\end{tabular}

В зависимости от сроков посева в смеси компоненты сфрормировали разное количество белка. Содержание белка в зерне компонента озимой ржи колебалась от $12,50 \%$ (вариант «срок посева 5 сентября») до 14,00 \% (вариант «срок посева 5 августа»). Соответственно сбор белка с 1 га составил 0,13 и 0,20 т. За период сроков посева с 15 августа по 25 августа сбор белка с 1 га оставался на одном уровне - 0,19 т.

Для зерна озимой вики в зерносмеси отмечалось снижение содержания белка при сроках посева от 5 августа по 5 сентября на 4,0\%.

Общий сбор белка в зерносмеси формировался от 0,30 т/га при сроке посева 5 сентября до 0,42 т/га при сроке посева 15 августа. Наибольшее общее содержание белка в зерносмеси синтезируется до срока посева 25 августа, а затем идет снижение данного показателя до 16,30 \% при сроке посева 5 сентября.

Оценка смешанных посевов по продуктивности агроценозов всегда оставалась спорной и неоднозначной. По данному вопросу спорят не только агрономы-растениеводы, но и ботаники, геоботаники, фитоценологы и представители других наук в области биологии. В свое время академик В.Н. Сукачев (1956) отмечал, что взаимоотношения растений (видов) между собой в биоценозе оцениваются по трем категори- ям: 1) конкуренция между собой из-за средств жизни (контактные); 2) влияние одних видов на другие через изменение фризических и химических свойств среды их обитания (трансабиотические); 3) воздействие одних видов на другие за счет деятельности микроорганизмов (трансбиотические) $[24,25]$. Здесь не исключение травосмесь «озимая рожь+озимая вика», состоящая из двух видов разных семейств, а озимая вика, в частности, взаимодействует в процессе с клубеньковыми бактериями.

Поэтому недостаточно сделать вывод только по урожайности зерна и его качеству в зерносмеси. Возникает вопрос - имеет ли смысл сформировать бинарные посевы данных культур в отличии от одновидовых, насколько приемлема их биологическая оценка? Формирование продуктивности растений в смешанных посевах происходит в жесткой межвидовой конкуренции за свет, воду, площади питания. Одним из критериев эфффективности смешанных посевов является показатель LER - «отношение земельных эквивалентов». Данный коэфффициент показывает размер площади земли, необходимой для получения в монокультурах того же количества продукции каждого из компонентов, которое сфрормировалось на единице площади смешанного посева [26]. Итак, чем выше значе- 
ние LER, тем выше эфффективность использования земли при выращивании смеси. Если отношение земельных эквивалентов равно 1, то возделывать культуры в смеси неэфффективно с точки зрения получения продукции [27]. Этот показатель рассчитывается по формуле:

$$
\operatorname{LER}=\left(\mathrm{Y}_{\mathrm{AB}} / \mathrm{Y}_{\mathrm{AA}}\right)+\left(\mathrm{Y}_{\mathrm{BA}} / \mathrm{Y}_{\mathrm{BB}}\right) \text {, }
$$

где LER - отношение земельных эквивалентов; $Y_{\text {Ав }}$ - урожайность культуры А в смешанном посеве с культурой $\mathrm{B}, \mathrm{T} /$ га; $\mathrm{Y}_{\mathrm{BA}}$ - урожайность культуры В в смешанном посеве с культурой А, т/га; $\mathrm{Y}_{\mathrm{AA}}$ и $\mathrm{Y}_{\mathrm{BB}}-$ урожайность соответственно культур А и В в чистом посеве, т/га [28].
В наших исследованиях показатель LER от сроков посева зерносмеси в среднем изменился от 1,04 до 1,12. То есть обеспечивалась биологическая эфффективность смешанных агроценозов озимой ржи с озимой викой в условиях лесостепи Западной Сибири. По годам исследования показатель LER изменился от 1,01 при сроке посева 5 сентября (2015 г.) до 1,24 при посеве 5 августа (2016 г.). Устойчивый показатель LER травосмеси «озимая вика+озимая рожь» обеспечивался при сроке посева культур с 15 по 25 августа (табл. 3).

\section{Урожайность зерна и биологическая эффективность озимых культур и их смесей в зависимости от сроков посева (2015-2017 гг.)}

\begin{tabular}{|c|c|c|c|c|c|c|c|c|}
\hline \multirow{3}{*}{$\begin{array}{c}\text { Срок } \\
\text { посева }\end{array}$} & \multirow{3}{*}{$\begin{array}{c}\text { Озимая } \\
\text { рожь }\end{array}$} & \multirow{3}{*}{$\begin{array}{c}\text { Озимая } \\
\text { вика }\end{array}$} & \multicolumn{6}{|c|}{ Смесь озимой вики с озимой рожью } \\
\hline & & & \multicolumn{2}{|c|}{ Озимая рожь } & \multicolumn{2}{|c|}{ Озимая вика } & \multicolumn{2}{|c|}{ Зерносмесь } \\
\hline & & & т/га & LER & т/га & LER & т/га & LER \\
\hline \multicolumn{9}{|c|}{2015 г. } \\
\hline 05.08 & 2,04 & 2,00 & 1,31 & 0,64 & 0,94 & 0,47 & 2,25 & 1,11 \\
\hline 15.08 & 2,44 & 2,40 & 1,54 & 0,63 & 0,91 & 0,38 & 2,45 & 1,01 \\
\hline 25.08 & 2,25 & 2,25 & 1,51 & 0,67 & 0,92 & 0,41 & 2,43 & 1,08 \\
\hline 05.09 & 2,00 & 1,75 & 0,92 & 0,46 & 0,96 & 0,55 & 1,88 & 1,01 \\
\hline \multicolumn{9}{|c|}{2016 г. } \\
\hline 05.08 & 2,03 & 2,20 & 1,45 & 0,71 & 0,85 & 0,39 & 2,30 & 1,24 \\
\hline 15.08 & 2,30 & 2,5 & 1,63 & 0,71 & 0,87 & 0,35 & 2,50 & 1,06 \\
\hline 25.08 & 2,30 & 2,3 & 1,56 & 0,68 & 0,92 & 0,40 & 2,48 & 1,08 \\
\hline 05.09 & 2,05 & 1,8 & 1,06 & 0,52 & 0,96 & 0,53 & 1,96 & 1,05 \\
\hline \multicolumn{9}{|c|}{2017 г. } \\
\hline 05.08 & 2,02 & 2,10 & 1,21 & 0,60 & 0,84 & 0,41 & 2,05 & 1,01 \\
\hline 15.08 & 2,10 & 2,21 & 1,37 & 0,65 & 0,88 & 0,40 & 2,25 & 1,05 \\
\hline 25.08 & 2,00 & 2,14 & 1,29 & 0,66 & 0,94 & 0,44 & 2,23 & 1,10 \\
\hline 05.09 & 1,65 & 1,55 & 0,82 & 0,50 & 0,92 & 0,60 & 1,74 & 1,10 \\
\hline \multicolumn{9}{|c|}{ Среднее за 2015-2017 гг. } \\
\hline 05.08 & 2,03 & 2,15 & 1,45 & 0,71 & 0,75 & 0,35 & 2,20 & 1,12 \\
\hline 15.08 & 2,28 & 2,37 & 1,44 & 0,63 & 0,96 & 0,41 & 2,40 & 1,04 \\
\hline 25.08 & 2,23 & 2,28 & 1,47 & 0,66 & 0,91 & 0,40 & 2,38 & 1,06 \\
\hline 05.09 & 1,90 & 1,7 & 0,93 & 0,49 & 0,93 & 0,55 & 1,86 & 1,04 \\
\hline
\end{tabular}

\section{Выводы}

1. Сроки посева озимых культур и их смеси с 5 августа по 5 сентября обеспечили урожайность зерна: озимой ржи - от 1,90 до 2,28 т/га;

Таблица 3 
$14,00 \%$; озимой вики - 24,00 \%. В бинарных посевах наибольшее накопление валового белка было получено при сроке посева 15 августа $17,50 \%$.

3. Бинарная смесь озимой вики с озимой рожью в условиях лесостепи Западной Сибири биологически эфффективна во все сроки посевов - от 5 сентября по 5 августа. Коэффицциент LER составил от 1,04-1,12.

Рекомендации производству. В целях получения наибольшей продуктивности озимой вики и озимой ржи в одновидовых и бинарных посевах в условиях лесостепи Западной Сибири сроки посева необходимо проводить с 15 по 25 августа.

\section{Литература}

1. Косолапов В.М., Трофимов И.А., Трофиимова Л.С., Яковлева Е.П. Рациональное природопользование и кормопроизводство в сельском хозяйстве России. - М.: Изд-во $\mathrm{PAH}, 2018 .-132 \mathrm{c}$.

2. Банкрутенко А.В., Юдина Е.В. Повышение эфффективности полевого кормопроизводства в подтайге Омской области // Вестн. КрасГАУ. - 2018. - № 4. - С. 26-30.

3. Байкалова Л.П., Едимеичев Ю.Ф., Машанов А.И. Оценка урожайности культурных пастбищ в условиях Красноярского края // Вестн. КрасГАУ. - 2019. - № 8. - С. 52-58.

4. Кашеваров Н.И., Нурльгаянов Р.Б., Межевич А.Л. Озимая рожь - важная кормовая культура в Сибирском федеральном округе // Кормление сельскохозяйственных животных и кормопроизводство. - 2013. - № 10. C. 3-6.

5. Нурльгаянов Р.Б. Организация сельскохозяйственного производства в современных условиях: тридцатилетний путь председателя В.А. Горячева. - Кемерово: Изд-во КГСХИ, 2013. - 275 с.

6. Межевич А.Л., Нурльгаянов Р.Б., Султанова С.С. Эфрфективность использования озимой ржи на корм в Западной Сибири // Энергосберегающие технологии производства продукции растениеводства: мат-лы Всерос. науч.-практ. конф., посвящ. 85летию со дня рождения проф. Н.Р. Бахти- зина. - Уфра: Изд-во Башкирского ГАУ, 2013. - C. 110-114.

7. Нурльгаянов Р.Б., Межевич А.Л. Использование зерна озимой ржи в животноводстве // Наука, образование, общество: проблемы и перспективы развития: мат. межднунар. науч. конф. - Тамбов, 2013. - Ч. 10. - С. 158159.

8. Нурльгаянов Р.Б., Биктимиров Ю.М., Имамов Р.М. Возделывание вико-ржаной смеси // Кормопроизводство. - 1999. № 8. - С. 20.

9. Нурльгаянов Р.Б., Гайдук С.A., Аpeфин А.Л. Озимая вика (VICIA VILLOSA Roth.) в смеси с озимыми злаковыми на корм // Тенденции сельскохозяйственного производства в современной России: матлы XII Междунар. науч.-практ. конф. - Кемерово: Изд-во КГСХИ, 2013. - С. 190-196.

10. Арефин А.Л., Нурльгаянов Р.Б., Гайдук C.A. Озимая вика (Vicia villosa Roth.) в смешанных посевах // Аграрная наука сельскому хозяйству: мат-лы межднунар. науч. конф. - Барнаул, 2014. - Кн. 2. C. 20-21.

11. Трубников Ю.Н., Едимеичев Ю.Ф. Основные принципы органического земледелия и возможности их реализации для кормопроизводства в условиях малых форм хозяйствования // Вестн. КрасГАУ. - 2018. - № 6. C. $66-70$.

12. Нурльгаянов Р.Б., Арефин А.А., Филимонов А.Л. Мохнатая вика поможет // Территория Агро. - 2015. - № 6. - С. 22-24.

13. Парахин Н.В., Золотарев В.Н., Лаханов А.П., Тюрин Ю.С. Вика мохнатая (Vicia villosa Roth.) в кормопроизводстве Pocсии. - Орел: Изд-во ОрелГАУ, 2010. - 508 с.

14. Минеев В.Г. Агрохимия: учебник. - 2-е изд., перераб. и доп. - М.: Изд-во МГУ; КолосС, 2004. - 720 c.

15. Каюмов М.К. Программирование урожаев. М.: Московский рабочий, 1986. -182 с.

16. Державин Л.М., Попова Р.Н., Дегтярова Н.И., Муха Н.А. Методика разработки нормативов выноса и коэфффициентов использования питательных веществ сельскохозяйственными культурами из минеральных удобрений и почвы. - М., 1985. - 69 с. 
17. Нормативы для определения потребности сельского хозяйства в минеральных удобрениях. - М., 1985. - 338 с.

18. Доспехов Б.А. Методика полевого опыта (с основами статистической обработки результатов исследований). - 5-е изд., доп. и перераб. - М.: Агропромиздат, 1985. - 351 с.

19. Методика государственного сортоиспытания сельскохозяйственных культур. - М., 1989. - Вып. 2. - 194 с.

20. Кашеваров Н.И., Исмагилов Р.Р., Нурлыгаянов Р.Б., Данилов В.П. Возделывание озимой вики в лесостепи Западной Сибири: метод. рекомендации. - Уфра: Изд-во БГАУ, 2019. - 36 c.

21. Нурльгаянов Р.Б. Озимая вика. - Уфра: Изд-во БГАУ, 2019. - 87 с.

22. Арефин А., Нурльгаянов Р. Влияние минеральных удобрений на урожайность зерна смеси озимой ржи с озимой викой в условиях Западной Сибири // Международный сельскохозяйственный журнал. - 2019. № 4. - C. 51-53.

23. Акимова О.И. Осенний рост и развитие озимых культур // Вестн. КрасГАУ. - 2006. № 11. - С. 77-80.

24. Сукачев В.Н. О некоторых современных проблемах изучения растительного покрова // Ботанический журнал. - 1956. - № 4. C. $476-486$.

25. Работнов Т.A. Экспериментальная фитоценология. - М.: Изд-во МГУ, 1987. - 160 с.

26. Ламан Н.А., Самсонов В.П., Прохоров В.Н. и др. Методическое руководство по исследованию смешанных агрофитоценозов. Минск: Навука і тэхніка, 1996. -101 с.

27. Willey R.W., Rao M.A. A competitive ratio for quantifying competition between intercrops // Experimental Agriculture. - 1980. - Vol. 16, № 2. $-P$. 117-125.

28. Садохина Т.А. Биологическая эфффективность смешанных посевов зернофууражных культур // Современное состояние, традиции и инновационные технологии в развитии АПК. - Уфа: Изд-во Башкирского ГАУ, 2019. - C. 214-320.

\section{Literatura}

1. Kosolapov V.M., Trofimov I.A., Trofimova L.S., Yakovleva E.P. Racional'noe prirodopol'zovanie i kormoproizvodstvo $v$ sel'skom hozyajstve Rossii. - M.: Izd-vo RAN, 2018. $132 \mathrm{~s}$.

2. Bankrutenko A.V., Yudina E.V. Povyshenie effektivnosti polevogo kormoproizvodstva $\mathrm{V}$ podtajge Omskoj oblasti // Vestn. KrasGAU. 2018. - № 4. - S. 26-30.

3. Bajkalova L.P., Edimeichev Yu.F., Mashanov A.l. Ocenka urozhajnosti kul'turnyh pastbishch v usloviyah Krasnoyarskogo kraya // Vestn. KrasGAU. - 2019. - № 8. - S. 52-58.

4. Kashevarov N.I., Nurlygayanov R.B., Mezhevich A.L. Ozimaya rozh' - vazhnaya kormovaya kul'tura $v$ Sibirskom federal'nom okruge // Kormlenie sel'skohozyajstvennyh zhivotnyh i kormoproizvodstvo. - 2013. № 10. - S. 3-6.

5. Nurlygayanov R.B. Organizaciya sel'skohozyajstvennogo proizvodstva $v$ sovremennyh usloviyah: tridcatiletnij put' predsedatelya V.A. Goryacheva. - Kemerovo: Izd-vo KGSKHI, 2013. - $275 \mathrm{~s}$.

6. Mezhevich A.L., Nurlygayanov R.B., Sultanova S.S. Effektivnost' ispol'zovaniya ozimoj rzhi na korm v Zapadnoj Sibiri // Energosberegayushchie tekhnologii proizvodstva produkcii rastenievodstva: mat-ly Vseros. nauch.-prakt. konf., posvyashch. 85-letiyu so dnya rozhdeniya prof. N.R. Bahtizina. - Ufa: Izd-vo Bashkirskogo GAU, 2013. - S. 110-114.

7. Nurlygayanov R.B., Mezhevich A.L. Ispol'zovanie zerna ozimoj rzhi $v$ zhivotnovodstve // Nauka, obrazovanie, obshchestvo: problemy i perspektivy razvitiya: mat. mezhdnunar. nauch. konf. - Tambov, 2013. - CH. 10. -S. 158-159.

8. Nurlygayanov R.B., Biktimirov Yu.M., Imamov R.M. Vozdelyvanie viko-rzhanoj smesi // Kormoproizvodstvo. - 1999. - № 8. - S. 20.

9. Nurlygayanov R.B., Gajduk S.A., Arefin A.L. Ozimaya vika (VICIA VILLOSA Roth.) v smesi s ozimymi zlakovymi na korm // Tendencii sel'skohozyajstvennogo proizvodstva $\mathrm{V}$ sovremennoj Rossii: mat-ly XII Mezhdunar. nauch.-prakt. konf. - Kemerovo: Izd-vo KGSKHI, 2013. - S. 190-196. 
10. Arefin A.L., Nurlygayanov R.B., Gajduk S.A. Ozimaya vika (Vicia villosa Roth.) v smeshannyh posevah // Agrarnaya nauka sel'skomu hozyajstvu: mat-ly mezhdnunar. nauch. konf. - Barnaul, 2014. - Kn. 2. S. 20-21.

11. Trubnikov Yu.N., Edimeichev Yu.F. Osnovnye principy organicheskogo zemledeliya i vozmozhnosti in realizacii dlya kormoproizvodstva $\mathrm{v}$ usloviyah malyh form hozyajstvovaniya // Vestn. KrasGAU. - 2018. № 6. - S. 66-70.

12. Nurlygayanov R.B., Arefin A.A., Filimonov A.L. Mohnataya vika pomozhet // Territoriya Agro. 2015. - № 6. - S. 22-24.

13. Parahin N.V., Zolotarev V.N., Lahanov A.P., Tyurin YU.S. Vika mohnataya (Vicia villosa Roth.) v kormoproizvodstve Rossii. - Orel: Izd-vo OrelGAU, 2010. - 508 s.

14. Mineev V.G. Agrohimiya: uchebnik. - 2-e izd., pererab. i dop. - M.: Izd-vo MGU; KolosS, 2004. - $720 \mathrm{~s}$.

15. Kayumov M.K. Programmirovanie urozhaev. M.: Moskovskij rabochij, 1986. -182 s.

16. Derzhavin L.M., Popova R.N., Degtyarova N.I., Muha N.A. Metodika razrabotki normativov vynosa i koefficientov ispol'zovaniya pitatel'nyh veshchestv sel'skohozyajstvennymi kul'turami iz mineral'nyh udobrenij i pochvy. - M., 1985. $69 \mathrm{~s}$.

17. Normativy dlya opredeleniya potrebnosti sel'skogo hozyajstva $v$ mineral'nyh udobreniyah. - M., 1985. - $338 \mathrm{~s}$.

18. Dospekhov B.A. Metodika polevogo opyta (s osnovami statisticheskoj obrabotki rezul'tatov issledovanij). - 5-e izd., dop. i pererab. M.: Agropromizdat, 1985. $-351 \mathrm{~s}$.
19. Metodika gosudarstvennogo sortoispytaniya sel'skohozyajstvennyh kul'tur. - M., 1989. Vyp. 2. - 194 s.

20. Kashevarov N.I., Ismagilov R.R., Nurlygayanov R.B., Danilov V.P. Vozdelyvanie ozimoj viki v lesostepi Zapadnoj Sibiri: metod. rekomendacii. - Ufa: Izd-vo BGAU, 2019. $36 \mathrm{~s}$.

21. Nurlygayanov R.B. Ozimaya vika. - Ufa: Izd-vo BGAU, 2019. - $87 \mathrm{~s}$.

22. Arefin A., Nurlygayanov $R$. Vliyanie mineral'nyh udobrenij na urozhajnost' zerna smesi ozimoj rzhi s ozimoj vikoj v usloviyah Zapadnoj Sibiri // Mezhdunarodnyj sel'skohozyajstvennyj zhurnal. - 2019. № 4. - S. 51-53.

23. Akimova O.I. Osennij rost i razvitie ozimyh kul'tur // Vestn. KrasGAU. - 2006. - № 11. S. 77-80.

24. Sukachev V.N. O nekotoryh sovremennyh problemah izucheniya rastitel'nogo pokrova /I Botanicheskij zhurnal. - 1956. - № 4. S. 476-486.

25. Rabotnov T.A. Eksperimental'naya fitocenologiya. - M.: Izd-vo MGU, 1987. - $160 \mathrm{~s}$.

26. Laman N.A., Samsonov V.P., Prohorov V.N. idr. Metodicheskoe rukovodstvo po issledovaniyu smeshannyh agrofitocenozov. - Minsk: Navuka i tekhnika, 1996. -101 s.

27. Willey R.W., Rao M.A. A competitive ratio for quantifying competition between intercrops // Experimental Agriculture. - 1980. - Vol. 16, № 2. - R. 117-125.

28. Sadohina T.A. Biologicheskaya effektivnost' smeshannyh posevov zernofurazhnyh kul'tur // Sovremennoe sostoyanie, tradicii i innovacionnye tekhnologii $\mathrm{v}$ razvitii APK. Ufa: Izd-vo Bashkirskogo GAU, 2019. S. 214-320. 